\title{
Biological Hazards for Healthcare Workers: Occupational Exposure to Vancomycin-Resistant Staphylococcus aureus as an Example of a New Challenge
}

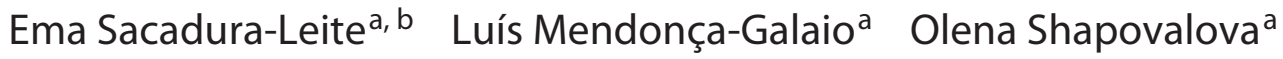 \\ Isabel Pereira ${ }^{a}$ Regina Rocha ${ }^{a}$ António Sousa-Uva ${ }^{b}$ \\ ${ }^{a}$ Department of Occupational Health, Centro Hospitalar Lisboa Norte, Lisbon, Portugal; ${ }^{b} \mathrm{CISP}$, Public Health Research \\ Center, Department of Occupational and Environmental Health, National School of Public Health, Universidade NOVA \\ de Lisboa, Lisbon, Portugal
}

\section{Keywords}

Biological hazards · Healthcare workers · Infections ·

Vancomycin-resistant Staphylococcus aureus $\cdot$ Hospitals

\begin{abstract}
Infections are among the most important occupational risks for healthcare workers. Some infections can be prevented through vaccination but, in other cases, there are no vaccines to prevent them, as happens with infections from antimicrobial-resistant organisms. Precautions related with transmission route and contact isolation or respiratory isolation are very important in order to protect healthcare workers and other patients. In this paper, the authors reviewed biological hazards for healthcare workers and described the procedures undertaken by an occupational health department (OHD) of a Portuguese hospital where vancomycin-resistant Staphylococcus aureus (VRSA) was isolated from a patient, for the first time in Europe. After the VRSA strain isolation, healthcare workers were instructed to adopt contact preventive measures. Nasal swabs were cultured weekly in 33 healthcare workers for several weeks until the patients' culture changed to negative. In the meantime, OHD prepared actions to adopt in case of VRSA colonization or infection in healthcare workers.
\end{abstract}

(c) 2018 The Author(s). Published by S. Karger AG, Basel on behalf of NOVA National School of Public Health

\section{KARGER}

E-Mail karger@karger.com www.karger.com/pjp

Karger Open access (c) 2018 The Author(s). Published by S. Karger AG, Basel on behalf of NOVA National School of Public Health

This article is licensed under the Creative Commons AttributionNonCommercial-NoDerivatives 4.0 International License (CC BYNC-ND) (http://www.karger.com/Services/OpenAccessLicense) Usage and distribution for commercial purposes as well as any distribution of modified material requires written permission.
Riscos biológicos emergentes em profissionais de saúde: exposição a Staphylococcus aureus resistente à vancomicina

\section{Palavras chave}

Riscos biológicos . Profissionais de saúde .

Staphylococcus aureus resistente à vancomicina .

Infeções · Hospitais

\section{Resumo}

As infeções constituem um importante grupo de riscos de natureza ocupacional para profissionais de saúde. Embora a vacinação seja uma forma eficaz de prevenir muitas infeções, algumas delas não dispõem de vacinas disponíveis. Os autores sintetizam neste artigo as principais vias de transmissão ocupacional de microrganismos a profissionais de saúde, dando enfase à transmissão de microrganismos resistentes a antibióticos que constituem um novo desafio em saúde ocupacional. Neste contexto, descrevem os procedimentos adotados pelo Serviço de Saúde Ocupacional de um hospital universitário português perante uma situação de exposição ocupacional de profissionais de saúde a um doente infetado com Staphy- 
lococcus aureus resistente à vancomicina (VRSA), o primeiro caso isolado na Europa. Depois do isolamento do agente, os profissionais foram instruídos para adotar as medidas de prevenção por contacto, efetuou-se a cultura das secreções nasais desses 33 profissionais semanalmente e estabeleceram-se os procedimentos a adotar perante colonização ou infeção dos profissionais de saúde.

(c) 2018 The Author(s). Published by S. Karger AG, Basel on behalf of NOVA National School of Public Health

\section{Introduction}

In hospitals, healthcare workers do a wide range of tasks, most of them related with patients' care. While performing their work, they are potentially exposed to many occupational hazards, including physical, chemical, biological, ergonomic-related, and psychological hazards. They can interact among each other in a complex way. For example, some health effects caused by biological agents can be prevented through vaccination, and the immune response can be affected by chronic stress [1]. In some circumstances, exposures to occupational hazards can be related to occupational diseases, work-related diseases, or occupational accidents. On the one hand, it is known that workers in healthcare settings and social workers have the fourth-highest rate of work-related diseases [2]. On the other hand, exposure to biological occupational hazards seems to be particularly prevalent in the healthcare sector [3]. In hospitals, infections are among the most important risks for healthcare workers. Most occupational health departments have well-organized programs, including vaccination programs, to prevent and to deal with some well-known biological hazards. Every once in a while, there comes the need to develop an action plan to deal with a new situation, as happens with infections from antimicrobial-resistant organisms. In this paper, we synthetize some information related with biological hazards to healthcare workers and we describe a specific occupational work situation, with a potential exposure of healthcare workers to vancomycinresistant Staphylococcus aureus in a European university hospital.

\section{Biological Hazards in Healthcare Settings}

Healthcare workers undertake their jobs in different workplaces in the hospital, doing a large range of activities. Therefore, they are potentially exposed to many

Biological Hazards for Healthcare Workers sources of infection. Laboratory workers are exposed to biological hazards during collecting or processing biological materials, while physicians and nurses are especially exposed when they perform surgical or invasive procedures, when they treat wounds, or when they take body fluid samples. Exposure to biological hazards is also common when nurses and nurse assistants take care of patients incapable of looking after themselves or when doctors make clinical examinations. Doing other activities, such as disinfecting, cleaning, transporting contaminated equipment, or working in contaminated areas, can also expose nurse assistants or other hospital workers to biological hazards in healthcare settings $[4,5]$.

The essential routes for the transmission of infections in healthcare settings are bloodborne, droplet, airborne, fecal-oral, and contact routes [6]. The main occupational risk for acquiring a blood pathogen in the healthcare setting, namely hepatitis $\mathrm{B}, \mathrm{C}$, and $\mathrm{D}$ viruses or human immunodeficiency virus (HIV), is a percutaneous sharp injury with a contaminated needle or other sharp object. Other possible routes of transmission include accidental exposure to blood or other organic fluids through a worker's broken skin or mucous membranes. The risk of transmission of bloodborne viruses following a single percutaneous exposure to blood containing a bloodborne virus depends upon several factors, but the average risk has been estimated to be the following: hepatitis B virus 33.3\% (1 in 3), hepatitis $\mathrm{C}$ virus $3.3 \%$ ( 1 in 30 ), and HIV $0.31 \%$ (1 in 319) [7]. A wide range of other microbiologic agents can be transmitted by percutaneous injury and they have to be considered if the patient has a known infection. Ebola virus is a very serious biological hazard transmitted by direct or indirect contact with organic fluids of infected patients. It is of great concern especially in some densely populated African regions, where an overlap between human and animal ecosystems exist, including primates and bats who are Ebola reservoirs. Nevertheless, this has also been a relevant problem for healthcare workers from Europe or North America who had worked with patients from countries where the infection is endemic or during epidemics $[4,5]$.

Airborne-transmitted infections include: measles, tuberculosis, chickenpox, and severe acute respiratory syndrome. Transmission of tuberculosis, caused by Mycobacterium tuberculosis, is a well-recognized risk to patients and healthcare workers. Microscopic droplets or droplet nuclei are produced by coughing, sneezing, and talking from patients with respiratory tuberculosis and they can remain suspended in the air for long periods and be dragged by air currents. The risk for healthcare work- 
Table 1. Some biological hazards for healthcare workers by routes of transmission

\begin{tabular}{|c|c|c|c|c|}
\hline Bloodborne & Droplet & Airborne & Fecal-oral & Direct contact \\
\hline Hepatitis B virus & Influenza virus & Measles virus & Escherichia coli & Sarcoptes scabiei \\
\hline Hepatitis $C$ virus & Rubella virus & Mycobacterium tuberculosis & Salmonella spp. & Herpes simplex virus 1 or 2 \\
\hline Hepatitis D virus & Neisseria meningitidis & Varicella zoster virus & Campylobacter jejuni/coli & Pseudomonas aeruginosa \\
\hline $\begin{array}{l}\text { Human immunodeficiency } \\
\text { virus }\end{array}$ & Mumps virus & & Rotavirus & $\begin{array}{l}\text { Vancomycin-resistant } \\
\text { Staphylococcus aureus }\end{array}$ \\
\hline
\end{tabular}

ers is higher when they perform some procedures where there is an increased exposure to tracheobronchial secretions, such as inducing sputum, secretion aspiration, bronchoscopies, autopsies, sputum testing, extubating/ intubating, and oral care, among others [6]. Prevention measures and medical monitoring of healthcare workers are useful to control occupational tuberculosis. The diagnosis of latent tuberculosis, which can be treated, in this way avoiding its progression to active tuberculosis, can be made by occupational health departments using tuberculin skin test and, more recently, interferon gamma release assays [8]. Rubella, measles, mumps, and varicella can be prevented through vaccination and must be considered an occupational hazard. Workers from pediatric departments and those working with immunocompromised patients, as in infectious diseases, hematology, oncology, and posttransplant wards, seem to have a higher risk of exposure. Meningitis, influenza, and other respiratory infections are spread through contact of infected respiratory secretions with healthcare workers' mucosae; therefore, the use of a chirurgical mask can significantly reduce the risk of transmission. Some of those infections, such as flu, can be prevented through vaccination.

Salmonella spp., Shigella spp., Campylobacter jejuni/ coli, Yersinia enterocolitica, enteropathogenic Escherichia coli, enterohemorrhagic Escherichia coli, rotaviruses, Clostridium difficile, and Vibrio cholerae are among the most serious agents that can be transmitted to healthcare workers by the fecal-oral route [4]. Skin infection agents, such as scabies agent or herpes simplex virus 1 or 2 , are transmitted by contact and they often infect healthcare workers. Enterococcus faecium, Staphylococcus aureus, Klebsiella pneumoniae, Acinetobacter baumannii, Pseudomonas aeruginosa, and Enterobacter spp. can be transmitted by contact too, but usually they do not cause infection in healthy people. Nevertheless, in some circumstances, they can cause serious health problems, namely pneumonia or infecting wounds. On the other hand, as healthcare workers become colonized with these agents, they can act as a vehicle for nosocomial dissemination. These factors are of special concern in healthcare settings, especially if they acquire resistance to antibiotics (Table 1).

\section{Antimicrobial-Resistant Microorganisms as an Example of a New Challenge for Occupational Health and Safety Departments in Hospitals}

Bacteria can develop resistance to antimicrobial agents. Antimicrobial-resistant organisms are one of the most serious health threats in healthcare settings for patients and for workers [9]. Healthcare workers are more likely exposed to antimicrobial-resistant organisms when they are taking care of their patients, particularly when patients are treated with large-spectrum antibiotics for a long period of time and when they are highly susceptible to infections [9].

As antimicrobial-resistant organisms spread in the same way as antimicrobial-susceptible ones, some disinfection control practices can prevent cross-contamination between patients and workers of both types of microorganisms. Those preventive practices include simple measures, such as washing hands and changing gloves before and after contact with patients [9], and other contact preventive measures, such as isolating infected or colonized patients. The hospital's policy towards a rational use of antibiotics is also very important.

Most of the time, healthcare workers can be carriers of pathogenic agents, including antimicrobial-resistant organisms, without developing infections. Nevertheless, sometimes an active infection may arise, being more susceptible if they have an existing severe illness, such as chronic renal disease, chronic respiratory disease among other chronic comorbidities and immunodepressive states. Other risk factors include recent antibiotherapy agents or healthcare workers undergoing an invasive procedure [10]. Some examples of antimicrobial-resistant organisms are methicillin/oxacillin-resistant Staphylo-
Sacadura-Leite/Mendonça-Galaio/ Shapovalova/Pereira/Rocha/Sousa-Uva 
coccus aureus (MRSA), vancomycin-resistant Staphylococcus aureus (VRSA), vancomycin-resistant enterococci (VRE), multi-resistant Escherichia coli and Salmonella, penicillin-resistant Streptococcus pneumoniae, carbapenem-resistant Klebsiella pneumoniae, carbapenem-resistant Acinetobacter baumannii, carbapenem-resistant Pseudomonas aeruginosa, and multidrug-resistant and extensively drug-resistant tuberculosis [9].

MRSA is a persistent problem in European hospitals, since the bacteria usually does not respond to the treatment with common antibiotics and it causes a high incidence of morbidity and mortality. These bacteria are highly resistant to dry and warm conditions and can survive as biofilms over inorganic environments (such as surfaces of medical devices) for a long period of time. The route of their transmission is through direct contact or via droplets. [6].

Vancomycin remains one of the first-line options for the treatment of infections with MRSA. Therefore, the emergence of vancomycin-resistant Staphylococcus aureus can create a very serious problem as there is low availability of alternative treatment and over the last two decades, there has been a significant retraction of investment towards antimicrobial research and development by the major pharmaceutical companies. Special concerns about VRSA exist in countries with a high prevalence of MRSA and VRE, because VRE can act as donors of genetic elements conferring resistance of MRSA to vancomycin. The first VRSA was identified and isolated in 2002 in the United States of America [11]. From 2002 to 2006, seven patients with Van-A VRSA were identified, all of them with a history of enterococcal infection or colonization and MRSA, underlying conditions, and vancomycin therapy prior to their VRSA infection [11].

\section{Potential Exposure to VRSA of Healthcare Workers in an Occupational Context}

The first case of VRSA infection identified in Europe was isolated in a central hospital of Lisbon in May 2013 [12]. A hospitalized 74-year-old female patient with diabetes mellitus type 2 , terminal chronic renal failure requiring hemodialysis, and peripheral vascular disease underwent amputation of two gangrenous toes. The resistant bacteria were recovered from pus of the toe amputation wound. At the time, the patient was being treated with vancomycin and amikacin because Pseudomonas aeruginosa and vancomycin-susceptible MRSA were previously isolated (March 2013) and she had clear signs of infection in the wound of the amputation site. Vancomycin-resis- tant Enterococcus faecalis and a VRSA strain (vancomycin minimum inhibitory concentration of $1,024 \mu \mathrm{g} / \mathrm{mL}$, determined by broth microdilution method according to the Clinical and Laboratory Standards Institute guidelines) [13] harboring the van A gene were isolated, along with vanA-positive vancomycin-resistant Enterococcus faecalis and Pseudomonas aeruginosa [14].

\section{Procedures Adopted in the Hospital}

After internal report of the situation by the microbiological department of the hospital, there was the involvement of several departments, including the occupational health department and the infection control committee. Some of the procedures immediately adopted included the reinforcement of infection control precautions and the monitoring of a possible dissemination of the VRSA strain in the hospital. The patient was initially screened for colonization by culturing swabs obtained from nares, axillae, perineum, and groin. Subsequently, she was weekly screened for nasal colonization until discharge from the hospital. Nasal swabs were also cultured from a total of 53 patients with whom she had close contact, including household members, 47 healthcare workers, and patients under hemodialysis in the same room as the index patient [14].

\section{Procedures Adopted by the Occupational Health \\ Department}

The patient was isolated and a restricted number of healthcare workers was selected and monitored while providing healthcare to the patient with VRSA infection. It was essential to limit and hold the patient's in-hospital care to the same healthcare workers throughout her hospital stay. Those healthcare workers were instructed to follow strict contact preventive measures in this context.

We also produced an internal guideline to help the occupational health department to manage and to screen healthcare workers exposed to VRSA and having had to continue treating the patient with VRSA infection. Basically, it included some actions to be operated in this situation, such as:

- Collecting weekly nasal swabs until the patient was clinically stable and cultures from her foot were negative for all the identified pathogens (August 2013);

- Defining the exact procedures to be followed in case of proven colonization:

- Immediate healthcare worker dismissal from workplace with justification of absences and payment;

- Mupirocin $20 \mathrm{mg} / \mathrm{g}$ (nasal ointment), with application t.i.d., for 8 days;

- Search for eventual early signs of infection. 
Table 2. Major procedures adopted by the occupational health department

1 Identification of all healthcare workers exposed to the patient

2 Nasal swabs of all healthcare workers previously identified

3 Selection of a restricted healthcare worker group to handle the infected patient

- Weekly nasal swab monitoring

4 Cooperation with the infection control committee

- Reinforcement of infection control precautions

5 Cooperation with the microbiologic department

- Creation of a swift communication method for nasal swab results

6 Cooperation with the department of human resources

- Creation of the possibility of immediate healthcare worker dismissal from workplace with absence justification and payment, in case of proven colonization or infection

7 Cooperation with the hospital pharmacy

- Supply of mupirocin for all colonized or infected healthcare workers

The management of all the procedures in case of colonization included a cooperation between the occupational health department and other departments, namely the microbiologic department, the department of human resources, and the hospital pharmacy (Table 2).

\section{Healthcare Workers' Nasal Swabs Results}

From 47 healthcare workers who first had contact with the patient before VRSA was isolated and who were initially screened from VRSA colonization, we monitored 33 hospital healthcare workers during 3 months (until August). Those monitored were the healthcare workers who remained providing health care to the patient until cultures of patient wound showed negative results. VRSA was not isolated from any of the screened individuals. Nevertheless, we identified 5 healthcare workers colonized with MRSA and 15 healthcare workers with methicillin-susceptible Staphylococcus aureus. Despite colonization, none of them showed signs of infection. We decided not to treat healthcare workers colonized with MRSA, once there was no evidence of epidemiologic transmission of MRSA.

\section{Discussion}

Healthcare workers are potentially exposed to a large number of microorganisms. Most of those biological hazards are well known and occupational health departments in hospitals have developed programs to manage the potential occupational risks. Some examples are the programs to manage accidental exposures to bloodborne pathogens or to manage Mycobacterium tuberculosis exposure.

Nevertheless, emergent risks have arisen, creating new challenges to occupational health departments, such as potential exposures to bacteria resistant to antibiotics.
An example of a new challenge presented in this article concerns a situation of healthcare workers' exposure to a patient with VRSA, the first known case in Europe. Fortunately, and in agreement with the results of the epidemiological studies conducted following isolation of VRSA strains in the USA $[11,15]$, transmission of VRSA identified in the index patient was not detected in healthcare workers, monitored during several weeks. The treatment of the patient with amikacin, daptomycin, and rifampicin during 6 weeks resulted in the nonidentification of the VRSA strain after 3 weeks. In addition to the positive response to the established therapy, we believe that the strict compliance with infection control measures certainly contributed to the nondissemination of the VRSA strain.

\section{Acknowledgments}

We thank the Department of Microbiology of the Centro Hospitalar Lisboa Norte, Lisbon, Portugal. This study did not receive any funding.

\section{Disclosure Statement}

The authors declare no conflict of interest.

\section{Author Contributions}

E. Sacadura-Leite wrote the paper, E. Sacadura-Leite, L. Mendonça-Galaio, O. Shapovalova, R. Rocha, and I. Pereira worked in the procedures implemented by the occupational health department in the VRSA exposure of healthcare workers. All authors read and contributed with their knowledge to the writing of the paper.
Sacadura-Leite/Mendonça-Galaio/

Shapovalova/Pereira/Rocha/Sousa-Uva 


\section{References}

1 Sacadura-Leite E, Sousa-Uva A: Occupational health departments in hospitals: can they contribute to a positive occupational psychology? In: Gonçalves SP, Neves JG, eds. Occupational health psychology: from burnout to wellbeing. Rosemead, CA: Scientific \& Academic Publishing 2011;1-16.

2 Eurostat. Health and safety at work in Europe (1999-2007): a statistical portrait. Luxembourg: Publications Office of the European Union; 2010. Available online: http://epp.eurostat.ec.europa.eu/cache/ITY_OFFPUB/ KS-31-09-290/EN/KS-31-09-290EN.PDF (accessed on 12.10.2016)

3 Eurofound. Fifth European Working Conditions Survey. Luxembourg: Publications Office of the European Union, 2012. Available online: http://www.eurofound.europa.eu/ pubdocs/2011/82/en/1/EF1182EN.pdf (accessed on 10.10.2016).

4 Sacadura-Leite E, Sousa-Uva A: Healthcare workers' health: old, new and emerging occupational hazards. In: SHO 2015: Proceedings of the International Symposium on Occupational and Safety Hygiene, Guimarães, Portugal, 12 e 13 de fevereiro de 2015. Guimarães: Sociedade Portuguesa de Segurança e Higiene Ocupacionais; 2015.
5 Cordeiro T, Sousa-Uva A, Sacadura-Leite E, Pinhal H, Nogueira A: Occupational hazards for healthcare workers in hospitals. In: Oddone E, ed. Occupational exposure and health risks. New York: Nova Scientce Publishers 2016, in print.

6 Directorate-General for Employment Social Affairs and Inclusion: Occupational health and safety risks in the healthcare sector: guide to prevention and good practice. Luxembourg: Publications Office of the European Union ; 2011. Available online: https://osha. europa.eu/en/tools-and-publications/publications/reports/7606488 (accessed on 10.09.2016).

7 European Agency for Safety and Health at Work: Current and emerging issues in the healthcare sector, including home and community care European. Luxembourg: Publications Office of the European Union; 2014. (Risk Observatory Report).

$>8$ Shapovalova O, Sacadura-Leite E, Galaio LM, Pereira I, Clemente R, Sousa-Uva A: Tuberculose latente em profissionais de saúde: concordância entre dois testes diagnósticos. Rev Port Saúde Pública 2016;34:3-10.

9 European Agency for Safety and Health at Work. Expert forecast on emerging biological risks related to occupational safety and health. Luxembourg: Publications Office of the European Union 2007.
10 de Jong T, Bos E, Pawlowska-Cyprysiak K, Hildt-Ciupinska K, Malinska M, Nicolescu G, et al: Current and emerging issues in the healthcare sector, including home and community care: European Risk Observatory report. Luxembourg: Publications Office of the European Union 2014.

11 Sievert DM, Rudrik JT, Patel JB, McDonald LC, Wilkins MJ, Hageman JC: Vancomycinresistant Staphylococcus aureus in the United States, 2002-2006. Clin Infect Diseases 2008; 46:668-674.

12 Melo-Cristino J.; Resina C, Manuel V, Lito L, Ramirez M: First case of infection with vancomycin-resistant Staphylococcus aureus in Europe. Lancet 2013;382:205.

13 Clinical and Laboratory Standards Institute: Performance standards for antimicrobial susceptibility testing: twenty-third informational supplement. Wayne, PA: Clinical and Laboratory Standards Institute; 2013. (CLSI Document M100-S23).

14 Friães A, Resina C, Manuel V, Lito L, Ramirez M, Melo-Cristino J: Epidemiological survey of the first case of vancomycin-resistant Staphylococcus aureus infection in Europe. Epidemiol Infect 2015;143:745-748.

15 Finks J, Wells E, Dyke TL, Husain N, Plizga L, Heddurshetti R, et al: Vancomycin-resistant Staphylococcus aureus, Michigan, USA, 2007. Emerg Infect Diseases 2009;15:943-945. 